\title{
Motives for self-referral to the emergency department: a systematic review of the literature
}

\author{
Nicole Kraaijvanger ${ }^{* *}$ (D) Henk van Leeuwen ${ }^{2}$, Douwe Rijpsma ${ }^{1}$ and Michael Edwards ${ }^{3}$
}

\begin{abstract}
Background: In several western countries patients' use of Emergency Departments (EDs) is increasing. A substantial number of patients is self-referred, but does not need emergency care. In order to have more influence on unnecessary self-referral, it is essential to know why patients visit the ED without referral. The goal of this systematic review therefore is to explore what motivates self-referred patients in those countries to visit the ED.

Methods: Recommendations from the PRISMA were used to search and analyze the literature. The following databases; PUBMED, MEDLINE, EMBASE, CINAHL and Cochrane Library, were systematically searched from inception up to the first of February 2015. The reference lists of the included articles were screened for additional relevant articles. All studies that reported on the motives of self-referred patients to visit an ED were selected. The reasons for self-referral were categorized into seven main themes: health concerns, expected investigations; convenience of the ED; lesser accessibility of primary care; no confidence in general practitioner/primary care; advice from others and financial considerations. A random-effects meta-analysis was performed.
\end{abstract}

Results: Thirty publications were identified from the literature studied. The most reported themes for self-referral were 'health concerns' and 'expected investigations': 36\% (95\% Confidence Interval 23-50\%) and 35\% (95\% Cl 20-51\%) respectively. Financial considerations most often played a role in the United States with a reported percentage of 33\% versus $4 \%$ in other countries $(p<0.001)$.

Conclusions: Worldwide, the most important reasons to self-refer to an ED are health concerns and expected investigations. Financial considerations mainly play a role in the United States.

Keywords: Self-referred patients, Emergency department, Systematic review

\section{Background}

The utilization of Emergency Departments (EDs) is increasing in several high-income countries $[1,2]$. Inappropriate presentations to EDs are a burden for healthcare systems, contributing to excess diagnostics and treatment, overcrowding of EDs and longer waiting times; all are associated with increasing health care costs

\footnotetext{
* Correspondence: n.kraaijvanger@hotmail.nl

${ }^{1}$ Emergency Department, Rijnstate Hospital, Wagnerlaan 55, Arnhem, The Netherlands

Full list of author information is available at the end of the article
}

[3-5]. This is important, because worldwide health care expenditures as a share of gross domestic product are increasing over the last years [6]. In addition, using the ED for primary care problems reduces continuity of care for patients.

Several countries experience high percentages of self-referred ED-patients. In England, $62.8 \%$ of EDpatients is self-referred [1]. In the United States (USA), relatively few general practitioners (GPs) are available and patients often self-refer to EDs or other types of specialized care [7]. In the Netherlands, despite its strong primary care network, $30 \%$ of ED-patients is self-referred [8]. Within the 
category of self-referred patients is a substantial number of patients that could have been taken care of in primary care. In a previous study, our group found that between 41.2 to $51.9 \%$ of self-referred patients in a Dutch ED visited the ED inappropriately [9]. This is crucial, because strategies that aim to reduce ED utilization should target inappropriate self-referral.

In order to reduce inappropriate self-referral, it is essential to know why patients visit the ED directly. The goal of this systematic review is to explore what motivates self-referred patients worldwide to visit the ED directly.

\section{Methods}

Recommendations from the Preferred Reporting Items in Systematic Reviews and Meta-Analysis (PRISMA) were followed [10].

\section{Search strategy and data sources}

The following five databases: PUBMED, MEDLINE, EMBASE, CINAHL and Cochrane Library, were systematically searched from inception up to the first of February 2015. Searches were conducted using a combination of the following search terms: emergency department, self-referred, referral, walk-in, motives and reasons with appropriate wildcards and variations in spelling. The search in Pubmed was as follows: "Emergency Service, Hospital" [Mesh] OR "emergency department" OR "emergency room" OR "emergency unit" OR "emergency service" OR "emergency ward") AND (self-refer* OR refer* OR walkin $\left.^{*}\right)$ AND (motiv* OR reason*), no limits were used. A similar search was conducted for the other databases.

The reference lists of the included articles were screened for additional relevant articles.

\section{Inclusion criteria}

Inclusion criteria were: study participants were selfreferred patients in the ED (not referred by a GP and not brought in by ambulance), the study reported on reasons for patients to visit the ED without referral. All age groups and all disease categories were included. Different methods to study these motives were accepted. Only articles in English and Dutch language were included.

\section{Data extraction}

Two authors (NK and HL) independently and in duplicate reviewed the titles and abstracts of retrieved publications and subsequently the full text was reviewed for possibly relevant articles. From the included articles, data on study purpose, design, setting, sample size, patient characteristics, study quality and country where the study was conducted was extracted. Disagreements were resolved by discussion until consensus was reached. The PRISMA flow diagram is shown in Fig. 1.

All different reasons for self-referral that were reported in the studies were listed. From these lists, seven themes for reasons for self-referral were identified by the study group (expert opinion) and consensus was reached within our group. Subsequently, the different reasons for self-referral that were found in the included articles were categorized into the seven themes. The themes were: health concerns; expecting investigations; convenience of the ED; lesser accessibility of primary care; no confidence in $\mathrm{GP} /$ primary care; advice from others; financial considerations (Appendix 1,2).

\section{Statistical analysis}

A random-effects meta-analysis was used in which all eligible studies were included. The meta-analysis was performed using the inverse variance method, with an empirical Bayes estimator for the heterogeneity parameter $\mathrm{tau}^{2}$, a Hartung-Knapp adjustment, and an arcsine transformation of proportions. Results of the primary studies were reported with Clopper-Pearson exact confidence intervals. The software $R$, version 4.1-0, package meta, from Guido Schwarzer (2015) was used [11].

In order to investigate whether the differences in reasons for self-referral could be explained by different healthcare systems or different study methods, the following subgroup analyses were performed: reporting on a specific condition; continent; including multiple choice questions; possibility to select multiple answers with multiple choice questions; including a Likert Scale; the year in which studies were published in; inclusion of only patients with non-urgent medical problems; and included age group (children, adults, all ages).

\section{Results \\ Selected studies}

Thirty studies were included, reporting motives for self-referral of 16450 patients [3, 5, 11-38]. The number of included patients differed considerably between the selected studies. Patient characteristics and study methodology were heterogeneous. Sixteen studies only included patients with non-urgent problems. [12, 14, 17, 19, 22, 24, 25, 27, 29-31, 34, 35, 37-39] Sixteen studies made use of questionnaires 


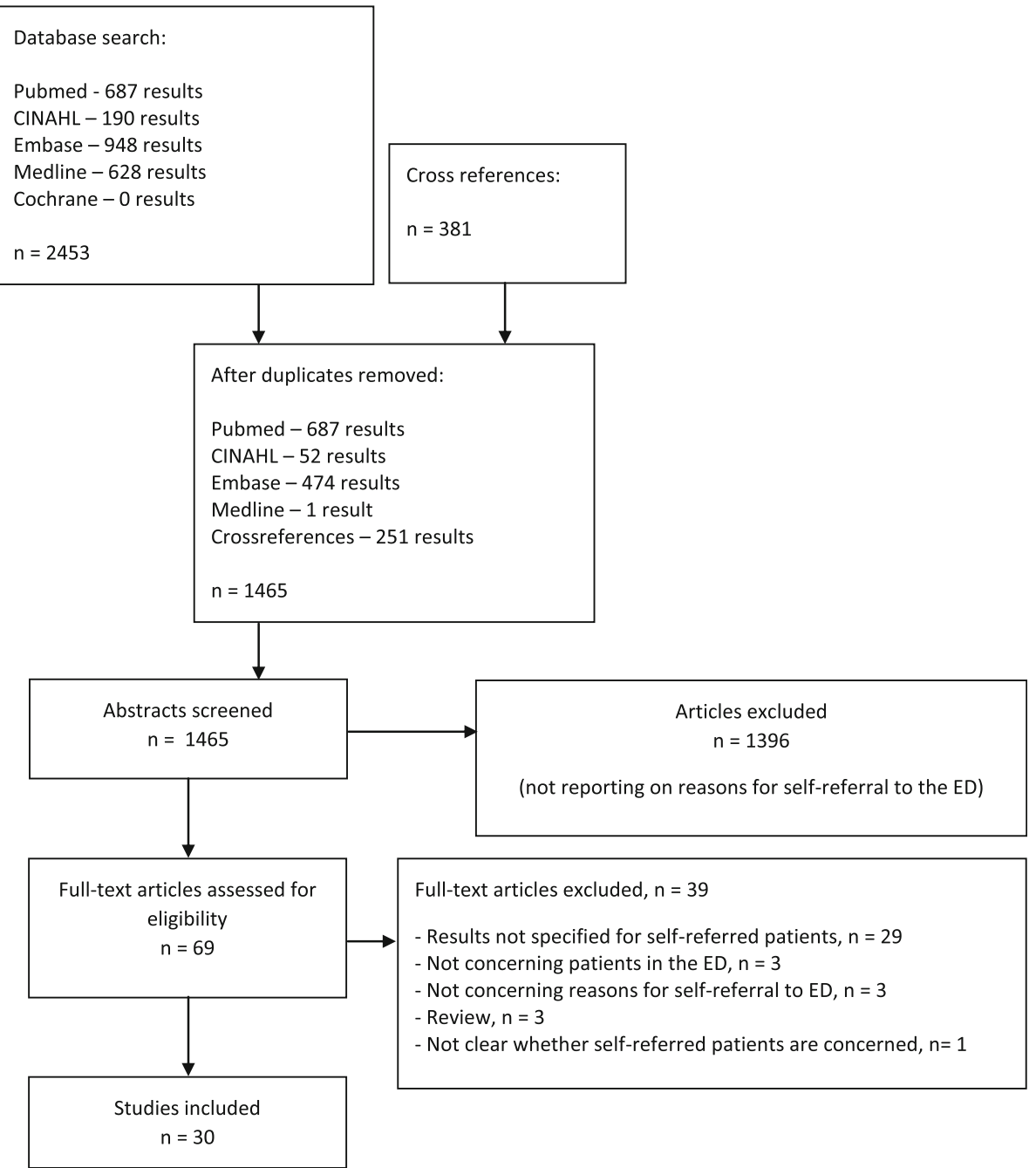

Fig. 1 PRISMA flow diagram

$[3,5,12,13,16-19,27,31-33,36-39]$, often with multiple choice questions $[3,5,12,13,16,19,22$, 27, 33, 37, 39] Three studies performed interviews with qualitative methodologies [29, 30, 34]. Others performed interviews without qualitative methods, sometimes by telephone, or by letting the treating physician or triage nurse ask one open question [14, 15, 20-26, 28, 31, 32, 35].

Most of the studies were performed in Europe and of the 19 European studies [3, 5, 11-27], 12 studies were performed in the United Kingdom (UK) [12, 14, $16,18,19,21-26,28]$. The remaining studies were performed in the Netherlands $[3,5,13,17,20]$, Ireland [15], Denmark [27], USA [29-34], Australia [37, 38], Hong Kong [35], Kuwait [36], and Israel [39] (Table 1).

\section{Reasons for self-referral}

Various motives for self-referral were found, with overlapping motives between studies. Percentages of the reasons reported by different studies were divergent. The reasons for self-referral were categorized into seven themes: health concerns; expecting investigations; convenience of the ED; lesser accessibility of primary care; no confidence in GP/primary care; advice from others; financial considerations. The different themes with examples are shown in Table 2 .

To find the most common reasons for self-referral, a meta-analysis was performed; the results are shown in Table 3.

Health concerns were reported by $36 \%$ of the patients. This theme was reported by studies from all 
Table 1 Selected studies, investigating motives for self-referral to the ED

\begin{tabular}{|c|c|c|c|c|c|}
\hline & Article & $\begin{array}{l}\text { Country, year } \\
\text { of publication }\end{array}$ & Method & Number of patients & Inclusion/exclusion \\
\hline \multicolumn{6}{|c|}{ Europe } \\
\hline 1 & Mestitz [28] & UK 1957 & $\begin{array}{l}\text { Questions asked by casualty } \\
\text { medical officer }\end{array}$ & 975 (770 SRPs) & Only adults? \\
\hline 2 & Wilkinson et al. [24] & UK 1977 & Interviews, using questionnaires & 546 (213 SRPs) & $\begin{array}{l}\text { All ages } \\
\text { Non-urgent }\end{array}$ \\
\hline 3 & Myers et al. [26] & UK 1982 & Question asked & 150 & Only adults? \\
\hline 4 & Singh [21] & UK 1988 & $\begin{array}{l}\text { Interviews, using semi-structured } \\
\text { questionnaire }\end{array}$ & 217 & All ages \\
\hline 5 & O'Halloran et al. [16] & UK 1989 & Postal questionnaires & 145 (124 SRPs) & $\begin{array}{l}\text { Age: } 18 \text { months to } \\
16 \text { years. } \\
\text { Acute asthma }\end{array}$ \\
\hline 6 & Stewart et al. [18] & UK 1989 & Questionnaires & 853 (585 SRPs) & Children \\
\hline 7 & Thomson et al. [19] & UK 1995 & Questionnaires & 245 (147 SRPs) & $\begin{array}{l}\text { Only adults? } \\
\text { Non-urgent }\end{array}$ \\
\hline 8 & Ward et al. [25] & UK 1996 & Question asked by treating physician & $\begin{array}{l}970 \\
\text { (339 patients answered } \\
\text { question) }\end{array}$ & $\begin{array}{l}\text { All ages } \\
\text { Non-urgent }\end{array}$ \\
\hline 9 & Laffoy et al. [15] & Ireland 1997 & Questionnaires, interviewer-administered & 557 (395 SRPs) & All ages \\
\hline 10 & $\begin{array}{l}\text { Shipman } \\
\text { et al. [23] }\end{array}$ & UK 1997 & Telephone interviews, semi-structured & 82 & All ages \\
\hline 11 & Rieffe et al. [17] & $\begin{array}{l}\text { Netherlands } \\
1999\end{array}$ & Questionnaires, Likert scale & 430 & $\begin{array}{l}\text { Only adults? } \\
\text { Non-urgent }\end{array}$ \\
\hline 12 & $\begin{array}{l}\text { Jaarsma-van Leeuwen } \\
\text { et al. [5] }\end{array}$ & $\begin{array}{l}\text { Netherlands } \\
2000\end{array}$ & Questionnaires & 1068 & $\begin{array}{l}\text { All ages } \\
\text { Only surgical patients }\end{array}$ \\
\hline 13 & Rajpar et al. [22] & UK 2000 & $\begin{array}{l}\text { Interviews, using semi-structured } \\
\text { questionnaire }\end{array}$ & 54 & $\begin{array}{l}\text { All ages } \\
\text { Non-urgent }\end{array}$ \\
\hline 14 & Coleman et al. [12] & UK 2001 & Questionnaires & 255 & $\begin{array}{l}\text { Adults } \\
\text { Non-urgent }\end{array}$ \\
\hline 15 & Norredam et al. [27] & $\begin{array}{l}\text { Denmark } \\
2007\end{array}$ & Questionnaire & 3426 (2746 SRPs) & $\begin{array}{l}\text { Age }>14 \text { years } \\
\text { Non-urgent }\end{array}$ \\
\hline 16 & $\begin{array}{l}\text { Moll van Charante } \\
\text { et al. [3] }\end{array}$ & $\begin{array}{l}\text { Netherlands } \\
2008\end{array}$ & Postal questionnaires & 808 (224 SRPs) & All ages \\
\hline 17 & Mc Guigan et al. [14] & UK 2010 & Interviews by telephone, semi-structured & 196 & $\begin{array}{l}\text { Age }>16 \text { years } \\
\text { Non-urgent }\end{array}$ \\
\hline 18 & $\begin{array}{l}\text { van der Linden } \\
\text { et al. [20] }\end{array}$ & $\begin{array}{l}\text { Netherlands } \\
2014\end{array}$ & Open question by triage nurse & $\begin{array}{l}3028 \\
\text { (1751 patients answered } \\
\text { question) }\end{array}$ & All ages \\
\hline 19 & de Valk et al. [13] & $\begin{array}{l}\text { Netherlands } \\
2014\end{array}$ & Questionnaires & 436 & Age $>18$ years \\
\hline \multicolumn{6}{|c|}{ North America } \\
\hline 20 & Hunt et al. [33] & USA 1996 & Questionnaires & 1538 & All ages \\
\hline 21 & $\begin{array}{l}\text { Koziol-McLain } \\
\text { et al. [34] }\end{array}$ & USA 2000 & Interviews, qualitative methodology & 30 & $\begin{array}{l}\text { Age }>18 \text { years } \\
\text { Non-urgent }\end{array}$ \\
\hline 22 & $\begin{array}{l}\text { Northington } \\
\text { et al. [31] }\end{array}$ & USA 2004 & Questionnaire + brief interview & 279 & $\begin{array}{l}\text { Age }>18 \text { years } \\
\text { Non-urgent }\end{array}$ \\
\hline 23 & Howard et al. [30] & USA 2005 & Interviews, qualitative methodology & 31 & $\begin{array}{l}\text { Age } 18-50 \text { years } \\
\text { Non-urgent }\end{array}$ \\
\hline 24 & Ragin et al. [32] & USA 2005 & $\begin{array}{l}\text { Interviews + questionnaires with } \\
\text { Likert scale }\end{array}$ & 1536 & Age $>18$ years \\
\hline 25 & Grant et al. [29] & USA 2010 & Interviews, qualitative methodology & 112 & Children \\
\hline
\end{tabular}


Table 1 Selected studies, investigating motives for self-referral to the ED (Continued)

\begin{tabular}{|c|c|c|c|c|c|}
\hline & & & & & Non-urgent \\
\hline \multicolumn{6}{|c|}{ Asia } \\
\hline 26 & Shah et al. [36] & Kuwait 1996 & Questionnaires, open ended question & 1146 & Only adults? \\
\hline 27 & Lee et al. [35] & $\begin{array}{l}\text { Hong Kong } \\
2000\end{array}$ & $\begin{array}{l}\text { Telephone interviews, using } \\
\text { questionnaires }\end{array}$ & $\begin{array}{l}2410 \\
\text { (726 patients answered } \\
\text { question) }\end{array}$ & $\begin{array}{l}\text { All ages } \\
\text { Non-urgent }\end{array}$ \\
\hline \multicolumn{6}{|c|}{ Australia } \\
\hline 28 & Masso et al. [38] & Australia 2007 & Questionnaire, Likert scale & 397 & $\begin{array}{l}\text { All ages } \\
\text { Non-urgent }\end{array}$ \\
\hline 29 & Siminski et al. [37] & Australia 2008 & Questionnaires & 400 & $\begin{array}{l}\text { All ages } \\
\text { Non-urgent }\end{array}$ \\
\hline \multicolumn{6}{|c|}{ Other } \\
\hline 30 & $\begin{array}{l}\text { Rassin } \\
\text { et al. [39] }\end{array}$ & Israel 2005 & Questionnaire & 73 & $\begin{array}{l}\text { Age }>18 \text { years } \\
\text { Non-urgent }\end{array}$ \\
\hline
\end{tabular}

SRPs self-referred patients

continents, and in studies including patients with urgent and non-urgent conditions [3, 12-18, 20-22, 24, 25, 27, 29, 31-33, 35-39].

Several factors that were related to the high variability in the reported percentages of health concerns were found. The two studies performed in

Table 2 Examples of the seven different themes

\begin{tabular}{|c|c|}
\hline Theme & Examples cited in articles \\
\hline Health concerns & $\begin{array}{l}\text { - Perceived severity of problem } \\
\text { - Seeking assurance } \\
\text { - Patient perceived the complaint } \\
\text { was urgent }\end{array}$ \\
\hline Expecting investigations & $\begin{array}{l}\text { - Further research (eg X-rays) was necessary } \\
\text { - Perceived facilities and investigations better } \\
\text { at A\&E } \\
\text { - See doctor and have tests/X-rays done in } \\
\text { same place }\end{array}$ \\
\hline Advice of others & $\begin{array}{l}\text { - On the advice of others } \\
\text { - Sent by someone (usually employer) } \\
\text { - They were referred by the staff (not the } \\
\text { doctor) in PCP's offices to be evaluated } \\
\text { in the ED }\end{array}$ \\
\hline Convenience of ED & $\begin{array}{l}\text { - Patient could get help earlier at the ED } \\
\text { - The ED was nearby } \\
\text { - Convenience of access }\end{array}$ \\
\hline Accessibility of GP & $\begin{array}{l}\text { - Patient could not reach the } \\
\text { GP/GP-cooperative } \\
\text { - Unavailability of GP } \\
\text { - Too long wait for family doctor }\end{array}$ \\
\hline Financial considerations & $\begin{array}{l}\text { - Payment flexibility } \\
\text { - Affordability } \\
\text { - Low cost }\end{array}$ \\
\hline No confidence in GP & $\begin{array}{l}\text { - Patient had no faith/trust in the GP } \\
\text { - Previous negative experience with the } \\
\text { GP/GP-cooperative } \\
\text { - Dissatisfied with GP }\end{array}$ \\
\hline
\end{tabular}

Australia [37, 38] found the highest percentage of patients indicating health concerns as a reason for self-referral: $74 \%$ (95\% CI 4-100\%), versus 48\% (95\% CI 2-98\%) in the USA [31-33], 25\% (95\% CI $13-$ $41 \%)$ in Europe [3, 12-18, 20-22, 24, 25, 27] and $24 \%(95 \%$ CI $0-100 \%)$ in Asia $[35,36](p=$ $0.0003)$.

Health concerns were reported in $14 \%$ (95\% CI 0$52 \%)$ in studies including only children $[16,18]$, versus $47 \%$ (95\% CI 14-81\%) in studies including only adults $[12-14,27,31,32,36,39]$ and 33\% (95\% CI 20-48\%) in studies including patients of all ages $[3,15,20-22,24$, $25,33,35,37,38](p=0.0014)$.

Both the year in which a study was published and the use of a Likert scale had a small influence on the heterogeneity regarding health concerns; reflected by an $\mathrm{I}^{2}$ remaining higher than $97 \%$.

Thirty-five percent of the self-referred patients visited the ED because they expected to need laboratory or radiological investigations. The studies reporting on this reason for self-referral were all conducted in either Europe $[3,5,12,13,15,21-23,26,28]$ or Australia [37, 38].

Studies performed in Australia reported that $63 \%$ (95\% CI $0-100 \%)$ of the included patients indicated this theme, compared to $28 \%$ (95\% CI 16-44\%) in studies from Europe $(p=0.01)$. Other subgroup analyses did not show significant associations.

The theme 'advice from others' was reported by $19 \%$ (PI 0-80\%) of self-referred patients. In studies including only non-urgent patients $[12,14,24,25,39]$ this theme was reported by $32 \%$ (95\% CI 7 - 65\%), versus $6 \%(95 \%$ CI 2 - 11\%) in studies also including urgent patients $[13,16,21,26]$. 
Table 3 Results of the meta-analysis, showing per theme the number of patients and studies and the percentage of patients indicating this theme as reason for their visit to the ED

\begin{tabular}{|c|c|c|c|c|c|c|}
\hline Theme & Number of studies & $\begin{array}{l}\text { Number of patients } \\
\text { in these studies }\end{array}$ & $\%$ patients & $95 \%$ Cl (\%) & $I^{2}(\%)$ & $95 \% \mathrm{PI}(\%)$ \\
\hline Health concerns & 22 & 5564 & 36 & $23-50$ & 99.7 & $0-94$ \\
\hline $\begin{array}{l}\text { Expecting investigations } \\
\text { (radiological/blood tests) }\end{array}$ & 10 & 1316 & 35 & $20-51$ & 98.1 & $1-85$ \\
\hline Advice of others & 9 & 346 & 19 & $6-37$ & 97.9 & $0-80$ \\
\hline Convenience of ED & 21 & 2939 & 18 & $11-26$ & 99.5 & $0-62$ \\
\hline Accessibility of GP & 17 & 1744 & 13 & $9-18$ & 92.4 & $0-36$ \\
\hline Financial considerations & 6 & 575 & 11 & $1-30$ & 99.1 & $0-74$ \\
\hline No confidence in GP & 5 & 93 & 5 & $1-15$ & 90.9 & $0-40$ \\
\hline
\end{tabular}

$\mathrm{Cl}$ Confidence Interval

$\mathrm{I}^{2}$ : the percentage of the total variation across studies due to heterogeneity; it takes values from $0-100 \%$ with the value of $0 \%$ indicating no observed heterogeneity

PI Prediction interval: expected 95\% range of outcomes, where the results of a new study would fall within

The year in which studies were performed also had an influence on the heterogeneity regarding the theme 'advice from others', which is probably explained by the fact that all studies published between 2000 and 2010 reporting on 'advice from others', included only non-urgent patients [12, 14, 39].

'Convenience of the ED' was reported by $18 \%$ (PI 0$62 \%)$ of self-referred patients. There were no subgroups with a significant relation to this theme.

The theme 'accessibility GP' was indicated by $13 \%$ (PI 0-36\%) of self-referred patients. Multiple studies found patients claiming their GP is not available or not having a personal GP $[3,5,12,13,17,20-26$, 29, 32, 35]. Several studies found patients declaring they did not think of their GP, were not aware of other services, such as a walk-in clinic or GPcooperative, or did not know the location of an alternative service $[5,11,12,21,22,32]$. Also within this theme, several studies found that patients turned to the ED, because they felt they had to wait too long for an appointment with their GP $[5,17,23,25,28$, 32] No statistically significant differences were found in subgroup analyses.

Financial considerations were reported by $11 \%$ (PI $0-74 \%)$ overall. Studies from the USA reported 33\% of patients visited the ED because of financial considerations [29, 31, 32], followed by $6 \%$ in Australia $[37,38] ; 3 \%$ in Asia [35] and $1 \%$ in Europe [15] $(P=$ 0.01). (Figure 2). Combining subgroups into non-GPbased countries (USA) versus GP-based-countries (remaining countries); we found 33\% against $4 \%$ of patients citing financial considerations as reason for self-referral $(P<0.0001)$ (Fig. 2).

Studies including only adults [31, 32] found 33\% (95\% CI $0-100 \%)$ reporting on financial considerations, versus studies including patients of all ages [15, 35, 37, 38], with $4 \%$ (95\% CI $0-10 \%),(P<0.0001)$.

Lack of confidence in their GP was reported by $5 \%$ (PI 0-40\%). Only studies from the UK [16, 24, 25] and the Netherlands $[6,13]$ reported on this reason for self-referral.

For none of the themes, the variation in the percentages could be explained by the use of multiple choice questions (with or without multiple possible answers) or the inclusion of only patients with a specific condition.

\section{Discussion}

EDs are designed to provide emergency care and are not ideal locations for primary care, because there is no continuity of care, there is a risk for unnecessary testing and an ED-visit is more costly than a primary care visit [40]. This review shows that health concerns and the expectation to need further investigations are the most frequently reported motives to visit an ED without referral. Both motives reflect patients worried about their health, seeking urgent medical care. This is remarkable, because sixteen out of thirty of the selected studies only included patients with non-urgent problems. Patients may often be unable to judge the severity of their condition and may view non-urgent symptoms as urgent.

These two most common motives are difficult to address; there will always be differences between self-assessed and clinically assessed urgency and patients can only be expected to act on their own perceptions. Awareness programs that have been studied showed a limited effect. In one study, performed in the USA, people received a booklet with 


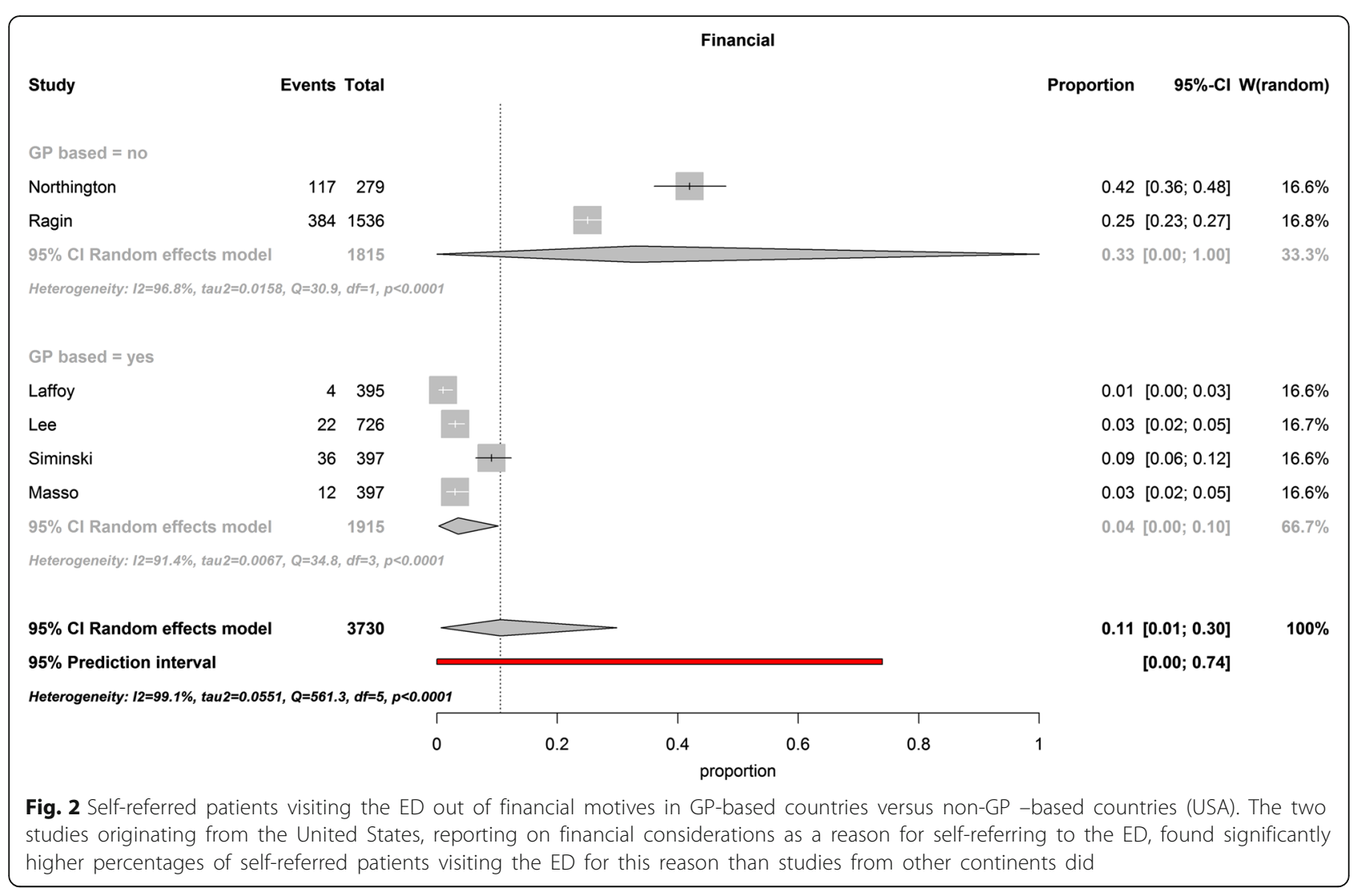

general information on when to visit an ED, but this did not show a significant effect on the number of ED-visits [41]. Education directed at specific conditions (ear pain in children, diabetes, asthma) and more intensive programs for geriatric or older, chronically ill patients have shown mixed results [42-47]. The effect of telephone consultation for patients to call for advice about their current health symptoms prior to seeking treatment at the ED also seems insufficient. In 1998, the UK introduced NHS Direct; a national nurse-led telephone advice service. Data suggested that this service reduced the number of calls to GPcooperatives, but did not have a significant impact on the number of ED-visits [48]. Since 2014, NHS Direct has been replaced by NHS 111 with better integration with other health services. However, also NHS 111 has failed to reduce the number of ED-visits [49]. In the Netherlands, the implementation of ECAPs, a system where patients who unnecessarily visit the ED can be triaged to GPs, showed promising results in decreasing ED-utilization [50].

Health care systems are different between countries. The largest differences consist of how primary care is organized and the charges patients face when consulting a
GP or ED. The results of this review should therefore be interpreted in the context of these health care systems.

\section{Europe \\ Health care system}

Most European studies were performed in the UK and the Netherlands. These countries have similar health care systems, which heavily rely on primary care and most patients have a personal GP. During out-of-office hours patients can visit GP-cooperatives or walk-in clinics to get primary care. GPs are supposed to act as gatekeepers to secondary or specialist care, but patients can attend the ED without a referral if their condition, in their opinion, seems sufficiently urgent to them. In the Netherlands, people have a deductible excess charge of $€ 385$ a year (in 2016); the first $€ 385$ of medical bills, including the costs of an ED-visit, are charged to the patient. In contrast, emergency care is free of charge in the UK. GP-care is free of charge in both countries [51-53].

Despite the well-developed primary care systems, both countries have substantial numbers of self-referred 
ED-visits. Hospital Episode Statistics reported that in 2012-13, 64.1\% of ED-visits (also including visits to minor injury units and walk-in centres) in England were self-referred [54]. In the Netherlands, $30 \%$ of ED-patients were self-referred in 2012 [8]. It has been shown that many of these patients visit the ED inappropriately $[9,52]$. At the same time, ED crowding and ED waiting times are increasing, which underlines the importance of reducing the number of inappropriate self-referred patients $[8,55,56]$.

\section{Study findings}

European studies found that patients reported visiting the ED because they expected that they needed laboratory or radiological investigations. Patients cannot get the same level of care with their GP and they visit an ED, when they expect that more advanced care will be necessary. A well-established primary care system does not change this.

Only studies from the UK and the Netherlands, reported a lack of confidence in their GP as a reason for self-referral to an ED, albeit with a low percentage. However, this is probably merely a reflection of the strong primary care network.

\section{Practice implications}

In the Netherlands, recent years an increasing number of EDs and GP-cooperatives are collaborating by creating Emergency Care Access Points (ECAPs) to reduce the number of self-referred ED-visits. During out-of-office hours, patients register at a conjoint desk, from where they are triaged to be seen by a GP or at the ED. This system shows promising results and is associated with an overall decrease in the number of ED-visits, almost disappearance of selfreferred patients and a higher probability of hospital admission [50].

\section{USA}

\section{Health care system}

The health care system of the USA, developed largely through the private sector, and combines high levels of funding with a low level of government involvement [57]. It has a small proportion of GPs and relies heavily on internal medicine and pediatrics for primary care [7]. In addition, the USA used to have a large proportion of uninsured or underinsured patients and patients often faced high cost sharing, including deductibles for primary care [57]. Because EDs are the only place where the poor could not be turned away, EDs were disproportionally used by low-income and uninsured patients who could not afford care in other settings [58]. In an attempt to deter inappropriate visits from EDs, several states implemented co-payments for non-emergency visits.

Recently, the health care system in the USA has undergone several changes, with the implementation of the Patient Protection and Affordable Care Act (PPACA) since 2010. With PPACA the percentage of uninsured patients is declining [59]. In addition, the funding for health centers was increased, which deliver preventive and primary health care to patients, regardless of their ability to pay. Between 2007-2015 these health centers have increased the number of patients served from 16 million, to 24 million annually [60].

Despite these measures, it seems that the number of ED-visits is still increasing: from 95 million in 1997, to 130 million in 2010 [61, 62]. In 2015, the American College of Emergency Physicians (ACEP) found that the majority of emergency physicians have noticed an increase in the volume of emergency patients since the requirement to have health coverage took effect in the PPACA in 2014 [63]. In addition, the number of EDs has decreased over the last years. Together, this leads to more overcrowded EDs [64].

\section{Study findings}

Studies from the USA reported significantly more frequently on issues with health-insurance and costs. This is to be expected, considering the charges patients faced when seeking medical care. However, all included studies were performed before the implementation of the PPACA, so it is not clear whether this affects the motivation of patients to visit the ED.

\section{Practice implications}

New research is necessary to see whether the motives for self-referral have changed since the PPACA was introduced.

\section{Australia}

\section{Health care system}

Australia has a complex health care system, with public and private funders and providers; including public and private hospitals with EDs. Medicare, the tax-funded national health insurance scheme, offers patients free, self-referred access to the ED. GPs act as gatekeepers to the rest of the health care system, 
since patients need a GP-referral to consult a specialist [65].

It is estimated that the number of public ED-visits increased by $3.4 \%$ on average each year between 2010 and 2015. In 2014-15 there were about 7.4 million EDconsultations in public hospitals; $75 \%$ of patients who visited the ED had an arrival mode of 'Other'; meaning they walked in or came by private or public transport, community transport or taxi. Ten percent were triaged as non-urgent [66].

\section{Study findings}

Studies from Australia found the highest percentage of patients visiting the ED out of health concerns and with the expectation to need investigations. There is no clear explanation for this finding.

\section{Practice implications}

Both motives are difficult to address.

\section{Overall}

Studies have shown that a strong primary care network may help to reduce the number of self-referred patients in the ED, especially when patients have access to a GP for immediate care [67]. In our study, $13 \%$ of self-referred patients visited the ED because of the limited accessibility of primary care. So, better organization of primary care, with fast and easy access, might reduce the relatively small, but substantial number of patients self-referring to for this reason. Remarkably, we found no difference between continents in the percentage of the theme accessibility of the GP' was reported, despite the varying accessibility of primary care in the different healthcare systems. This might be because this theme reflects patients not getting a timely appointment with their GP in one country versus not having a personal GP in another country. Despite the wellestablished primary care in Europe and Australia, the number of non-urgent patients in EDs is substantial. This may be caused by the fact that the countries that have well established primary care systems also have well established healthcare insurance systems and historically have low thresholds for seeking medical consultation.

The results of this study show that health concerns are a major motivation for patients to selfrefer to the ED, including for patients with nonurgent symptoms. This might be an important explanation for the limited effects of previous interventions; people who are worried about their health, will not be easily discouraged in seeking help at the ED. A solution in which a medical professional can triage self-referred patients to either a GP or the ED could relieve the patient of the burden of choosing the appropriate facility to present to, without discouraging patients to seek urgent medical care if needed. We believe the introduction of ECAPs may be that solution; the data on the effectiveness of ECAPs is promising, but is limited and subject to future research of our group.

\section{Strengths and limitations}

Strength of this study is that it reviews motives from self-referred patients worldwide, which provides data on what motives patients have to seek urgent medical care in EDs. These data can be used by policymakers to adjust healthcare systems in order to decrease selfreferral associated costs. In addition, this study interprets the results of this review by taking into account the differences of healthcare systems in which the studies were performed.

This study only includes studies in Dutch and English and might therefore have missed some relevant articles.

Seven articles used multiple choice questions, with the option of selecting multiple answers $[12,13,15$, 16, 33, 37, 39]. Unfortunately, it is not clear from these articles how many patients selected multiple answers. This makes it impossible to assess what reasons were most important for these patients in selfreferring to the ED.

This review could not explore whether motives for appropriate and inappropriate visits differ, because the included studies did not report on the appropriateness of ED-visits.

Large variations in reported percentages of reasons for self-referral between studies were found, reflected by wide prediction intervals and high levels of heterogeneity. Subgroup analyses were performed in order to analyze whether this could be explained by different healthcare systems or study methods, but not all heterogeneity could be explained. It is plausible that other, unknown factors that are not reported in the original manuscripts influence the reported percentages and the inability to explain reporting heterogeneity might therefore be.

\section{Conclusion}

Reasons for self-referral to EDs differ slightly with different healthcare systems. Worldwide, the most important reasons to self-refer to an ED are health concerns and additional investigations. Financial considerations mainly play a role in the United States. 


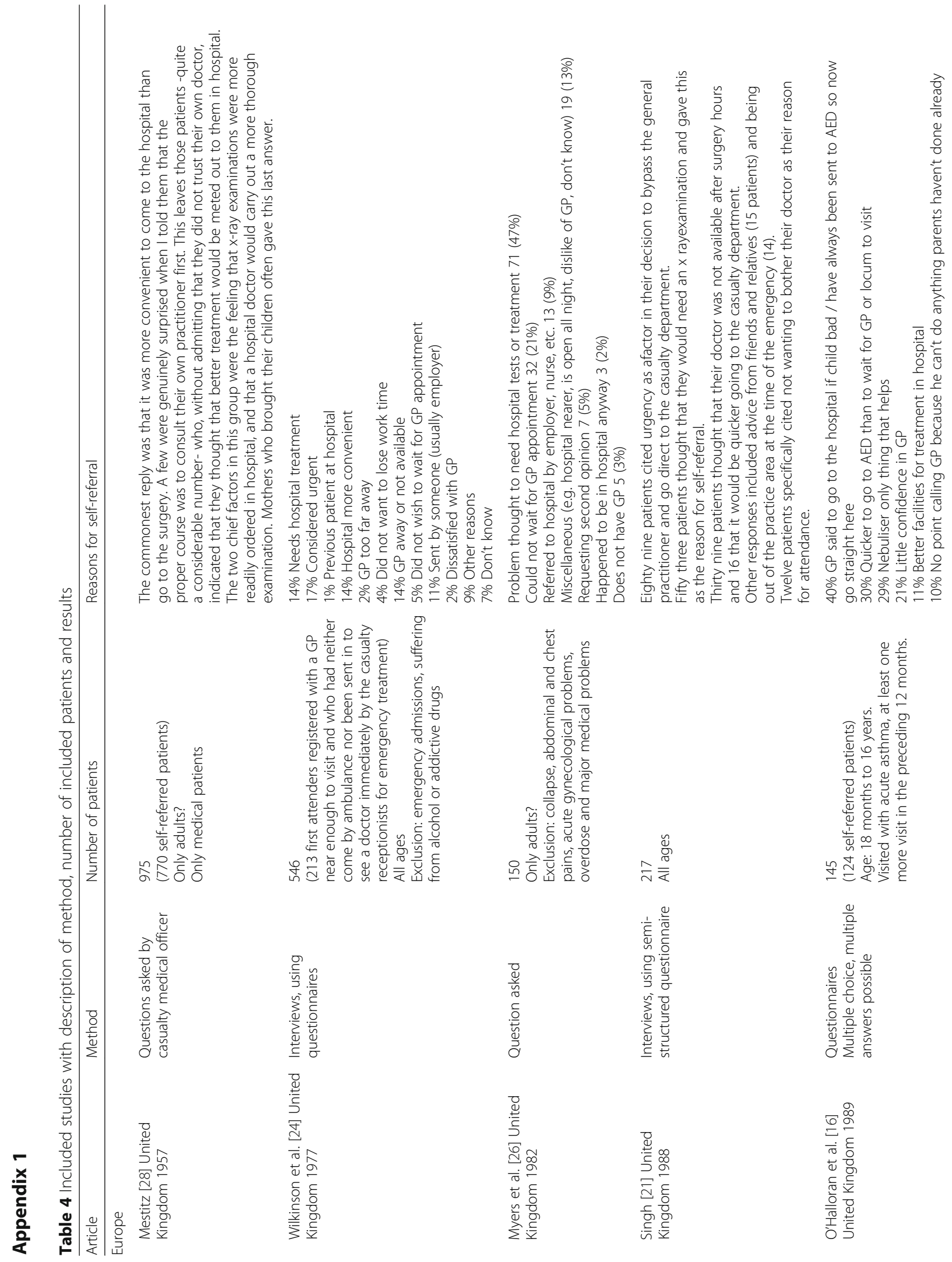




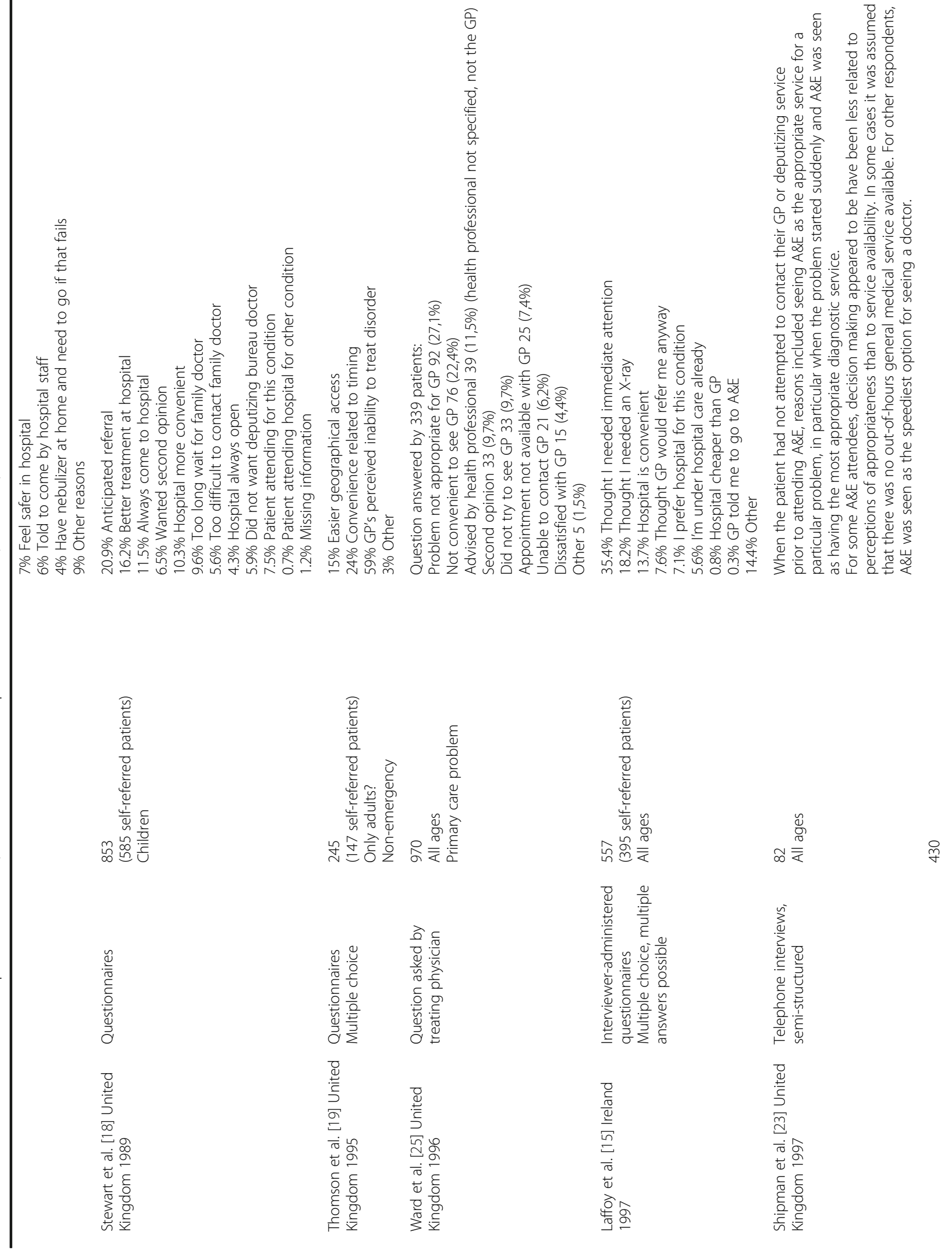




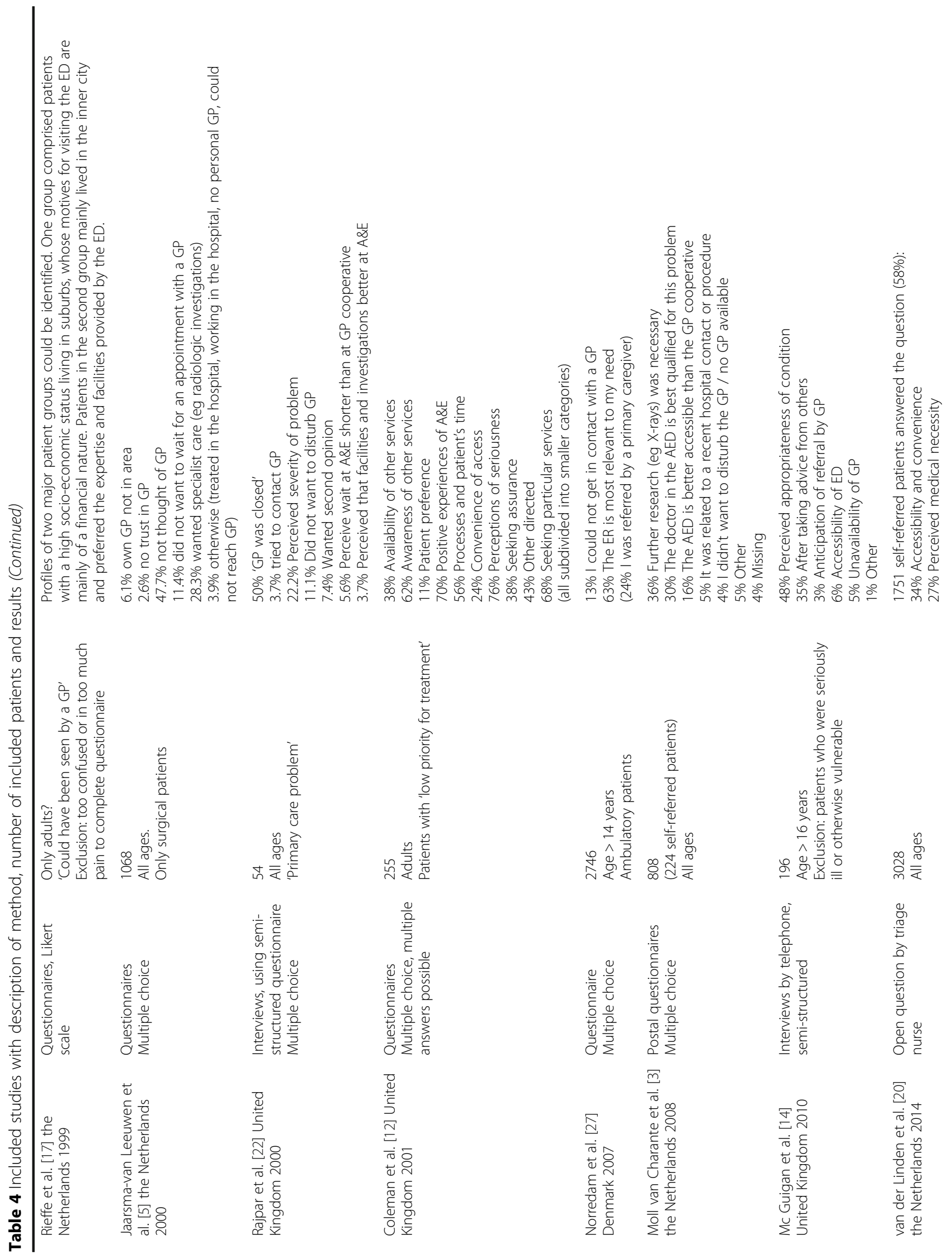




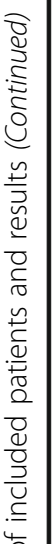

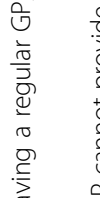

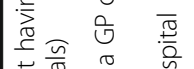

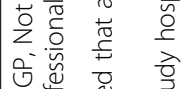

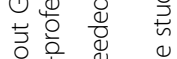

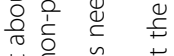

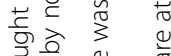

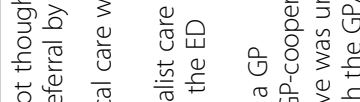

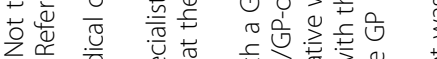

范守

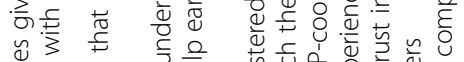

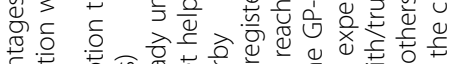

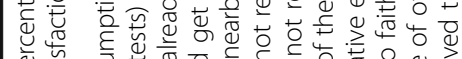

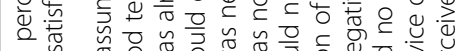

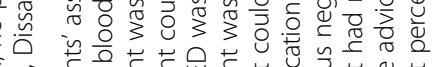

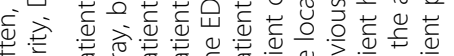

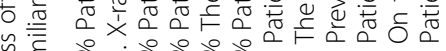

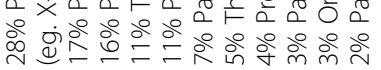

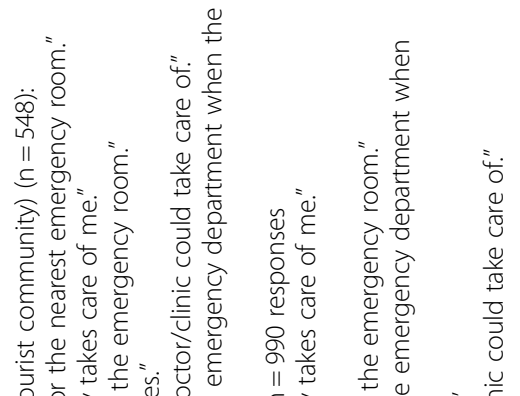

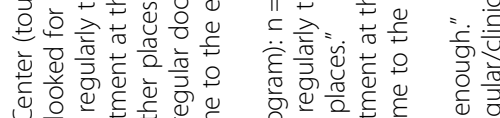

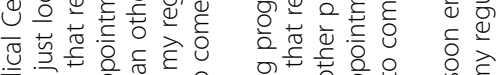

㖣.

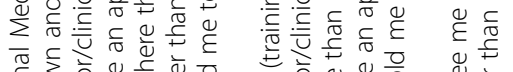

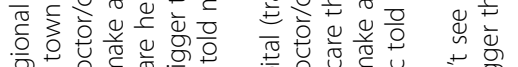

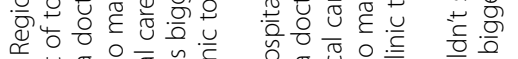

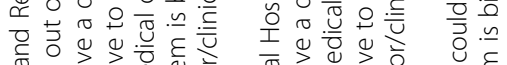

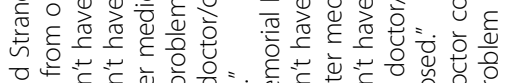

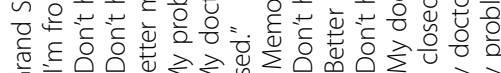

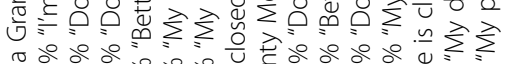

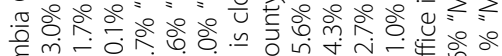

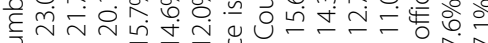

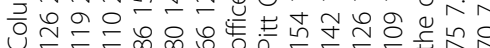

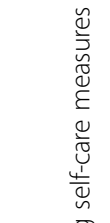

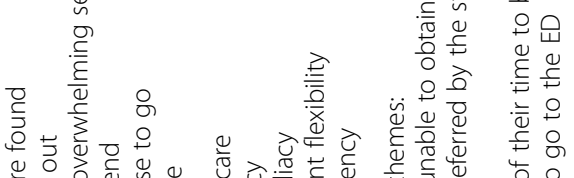
状:

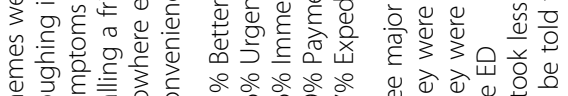

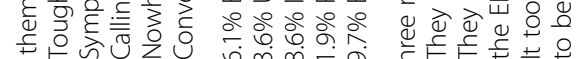

总莺

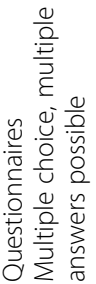

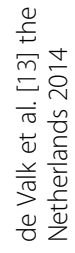

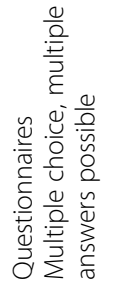

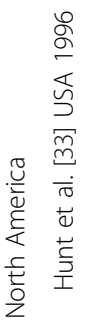

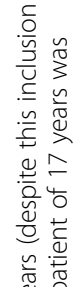

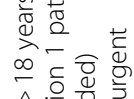

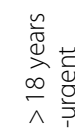

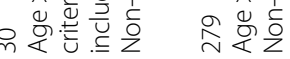

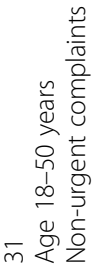

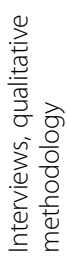

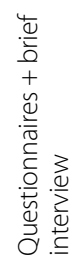

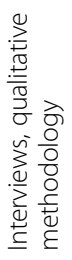

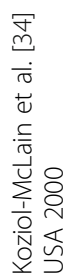

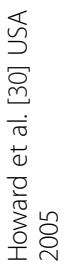




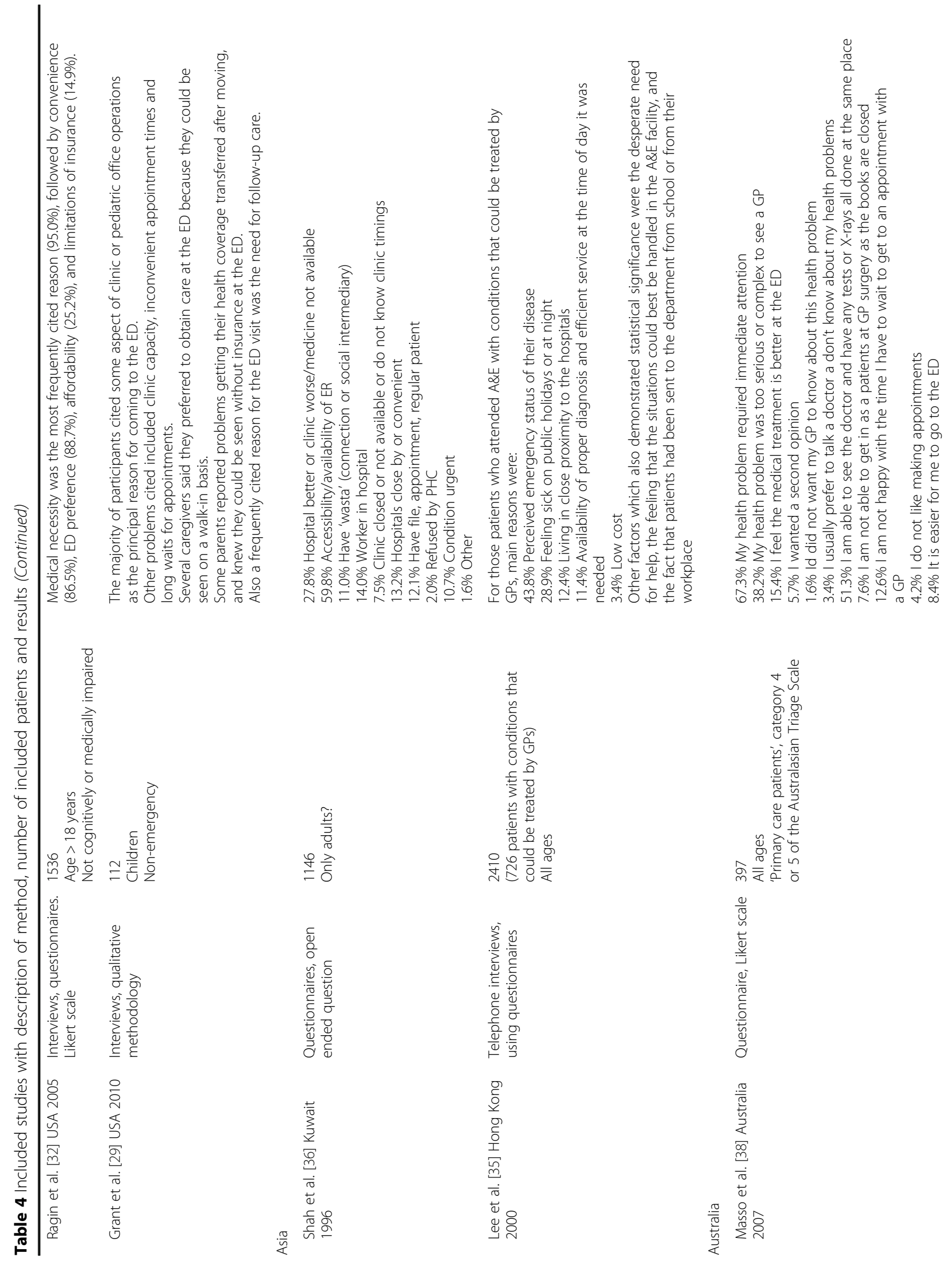


분

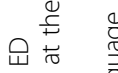

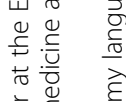

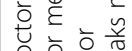

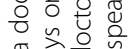

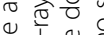

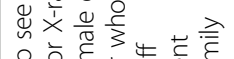

눈

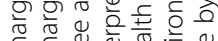

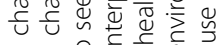

ट

苞

$\frac{8}{8}$

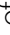

है

है

$\frac{\varepsilon}{4}$

들

莺

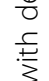

$\frac{\sqrt[n]{0}}{\frac{0}{3}}$

点

$\frac{\frac{d}{0}}{\frac{3}{y}}$

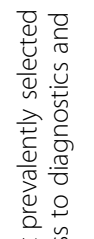

ن.

言咅 起

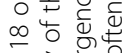

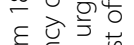

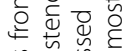

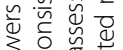

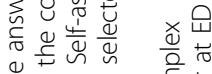

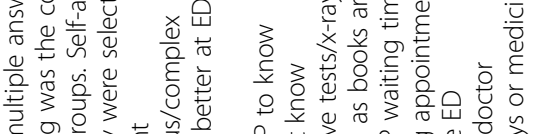

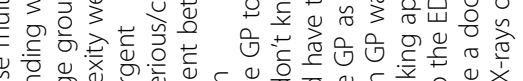

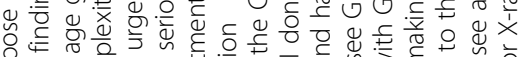

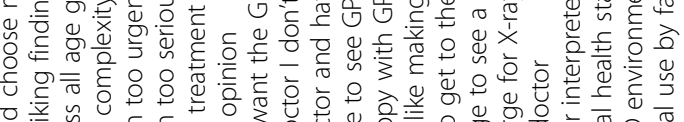

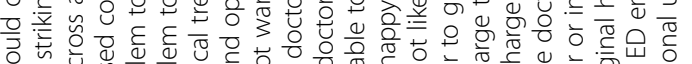

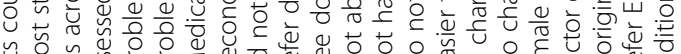

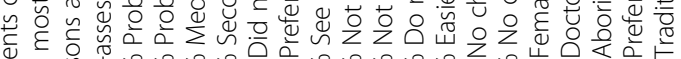

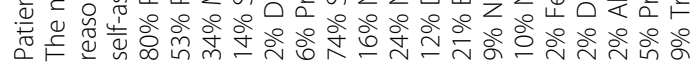

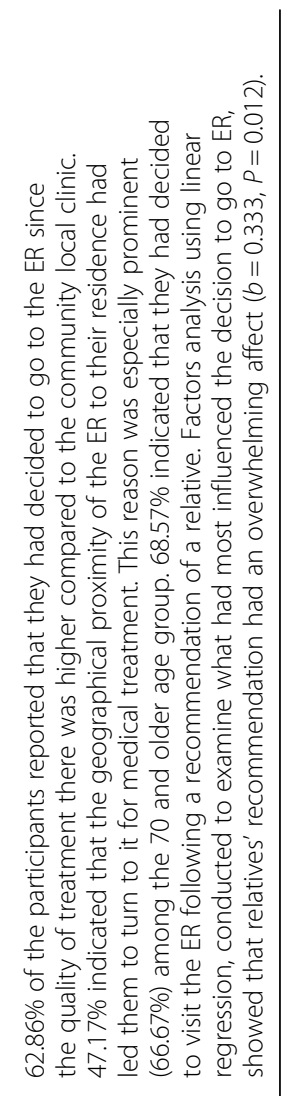

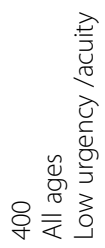

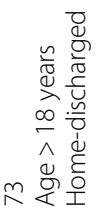

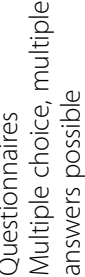

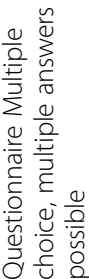

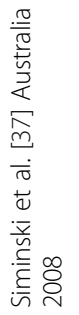

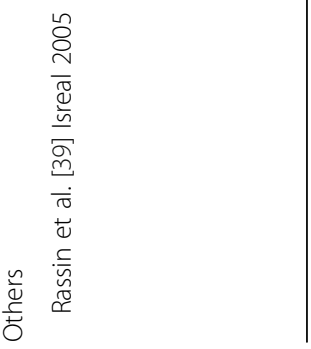




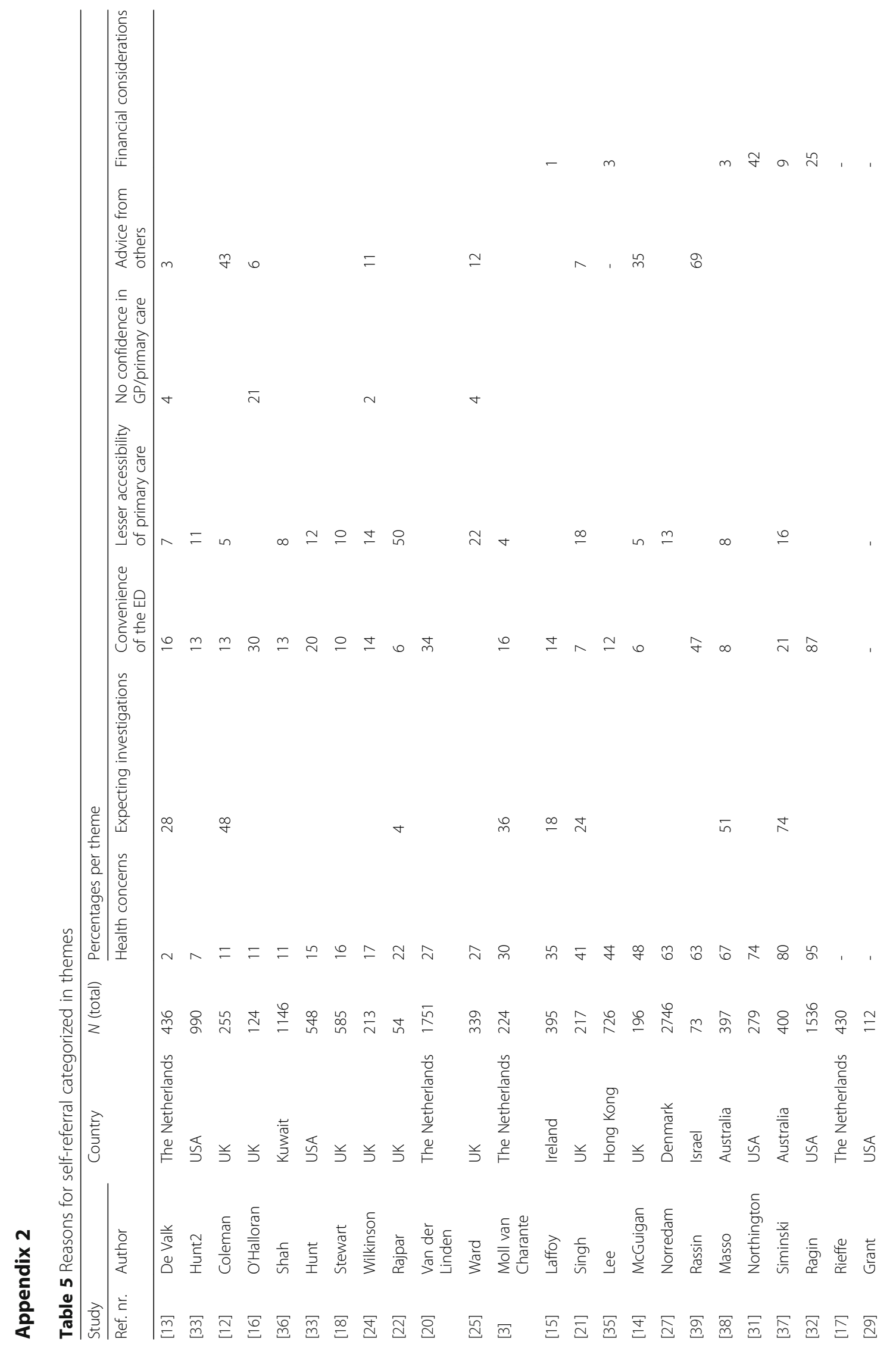




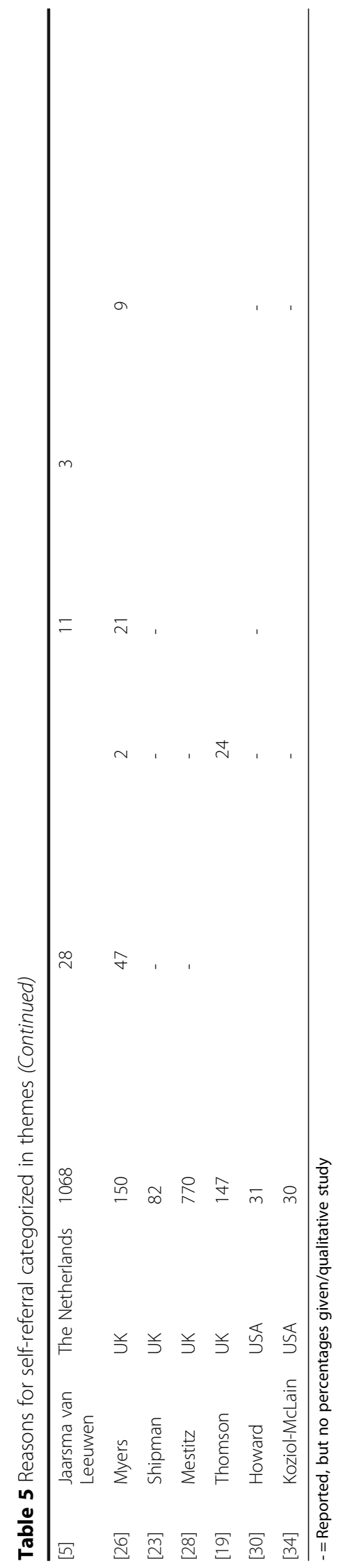




\section{Abbreviations}

Cl: Confidence interval; ECAP: Emergency care access point; ED: Emergency Department; GP: General practitioner; PI: Prediction interval; UK: United Kingdom; USA: United States of America

\section{Acknowledgements}

Not applicable.

\section{Funding}

None declared.

\section{Availability of data and materials}

All data generated or analysed during this study are included in this published article and its supplementary information files.

\section{Authors' contributions}

NK systematically searched five databases: PUBMED, MEDLINE, EMBASE, CINAHL and Cochrane Library. NK and HL identified additional articles by a cross-reference search. NK and $\mathrm{HL}$ reviewed the titles and abstracts of retrieved publications and subsequently reviewed the full text for possibly relevant articles. Statistical analysis was performed by Prof. Dr. Jelle Goeman (Professor bio-statistics) and Dr. Joanna in't Hout (statistician). NK wrote the manuscript, which was several times revised by HL, DK and ME. All authors read and approved the final manuscript.

\section{Competing interests}

The authors declare that they have no competing interests.

\section{Consent for publication}

Not applicable.

\section{Ethics approval and consent to participate}

Not applicable.

\section{Author details}

${ }^{1}$ Emergency Department, Rijnstate Hospital, Wagnerlaan 55, Arnhem, The Netherlands. ${ }^{2}$ Department of Intensive Care / Internal Medicine, Rijnstate Hospital, Wagnerlaan 55, Arnhem, The Netherlands. ${ }^{3}$ Department of Surgery, Radboud University Medical Centre, Geert Grooteplein-Zuid 10, Nijmegen, The Netherlands.

Received: 9 September 2016 Accepted: 6 December 2016

Published online: 09 December 2016

\section{References}

1. Health and Social Care Information Centre. Hospital Episode Statistics Accident and Emergency Attendances in England - 2014-15. 2016. https:// www.gov.uk/government/statistics/accident-and-emergency-attendances-inengland-2014-15. Accessed 10 July 2016.

2. Tang N, Stein J, Hsia RY, Maselli JH, Gonzales R. Trends and characteristics of US emergency department visits, 1997-2007. JAMA. 2010;304:664-70.

3. Moll van Charante EP, ter Riet G, Bindels P. Self-referrals to the a\&E department during out-of-hours: patients' motives and characteristics. Patient Educ Couns. 2008;70:256-65.

4. Sempere-Selva T, Peiró S, Sendra-Pina P, Martínez-Espín C, López-Aguilera I. Inappropriate use of an accident and emergency department: magnitude, associated factors, and reasons-an approach with explicit criteria. Ann Emerg Med. 2001;37:568-79.

5. Jaarsma-van Leeuwen I, Hammacher ER, Hirsch R, Janssens M. Patients without referral treated in the emergency room: patient characteristics and motives. Ned Tijdschr Geneeskd. 2000;144:428-31.

6. OECD.Stat. Health expenditure and financing; Share of gross domestic product. http://stats.oecd.org/ Accessed 10 Nov 2016.

7. Schoen C, Osborn R, Doty MM, Bishop M, Peugh J, Murukutla N. Toward higher-performance health systems: adults' health care experiences in seven countries, 2007. Health Aff. 2007:6:717-34.

8. Gaakeer Ml, van den Brand CL, Veugelers R, Patka P. Inventory of attendance at Dutch emergency departments and self-referrals. Ned Tijdschr Geneeskd. 2014;158:A7128.
9. Kraaijvanger N, Rijpsma D, van Leeuwen H, van Dijk N, Edwards M. Selfreferrals in a Dutch Emergency Department: how appropriate are they? Eur J Emerg Med. 2016; doi: 10.1097/MEJ.0000000000000216.

10. Moher D, Liberati A, Tetzlaff J, Altman DG, PRISMA Group. Preferred Reporting Items for Systematic Reviews and Meta-Analyses: The PRISMA Statement. PLoS Med. 2009; doi:10.1371/journal.pmed1000097.

11. Schwarzer G. meta: General Package for Meta-Analysis. R package version 4. 1-0. 2015. http://CRAN.R-project.org/package=meta. Accessed Jan 2016.

12. Coleman $P$, Irons $R$, Nicholl J. Will alternative immediate care services reduce demands for non-urgent treatment at accident and emergency? Emerg Med J. 2001;18:482-7.

13. de Valk J, Taal EM, Nijhoff MS, Harms MH, Lieshout EM, Patka P, et al. Selfreferred patients at the Emergency Department: patient characteristics, motivations, and willingness to make a copayment. Int J Emerg Med. 2014; doi: 10.1186/s12245-014-0030-7.

14. McGuigan T, Watson P. Non-urgent attendance at emergency departments. Emerg Nurse. 2010;18:34-8.

15. Laffoy M, O'Herlihy B, Keye G. A profile of attenders to a south Dublin city accident and emergency department. Ir J Med Sci. 1997;166:35-7.

16. O'Halloran SM, Heaf DP. Recurrent accident and emergency department attendance for acute asthma in children. Thorax. 1989:44:620-6.

17. Rieffe C, Oosterveld P, Wijkel D, Wiefferink C. Reasons why patients bypass their GP to visit a hospital emergency department. Accid Emerg Nurs. 1999;7:217-25.

18. Stewart MC, Savage JM, Scott MJ, McClure BG. Primary medical care in a paediatric accident and emergency department. Ulster Med J. 1989;58:29-35.

19. Thomson H, Kohli HS, Brookes M. Non-emergency attenders at a district general hospital accident and emergency department. J Accid Emerg Med. 1995:12:279-81.

20. van der Linden $M C$, Lindeboom $R$, van der Linden $N$, van den Brand $C L$, Lam RC, Lucas C, et al. Self-referring patients at the emergency department: appropriateness of ED use and motives for self-referral. Int J Emerg Med. 2014; doi: 10.1186/s12245-014-0028-1.

21. Singh S. Self referral to accident and emergency department: patients' perceptions. BMJ. 1988:297:1179-80.

22. Rajpar SF, Smith MA, Cooke MW. Study of choice between accident and emergency departments and general practice centres for out of hours primary care problems. J Accid Emerg Med. 2000;17:18-21.

23. Shipman C, Longhurst S, Hollenbach F, Dale J. Using out-of-hours services: general practice or A\&E? Fam Pract. 1997;14:503-9.

24. Wilkinson A, Kazantzis G, Williams DJ, Dewar RA, Bristow KM, Miller DL. Attendance at a London casualty department. J R Coll Gen Pract. 1977;27:727-33.

25. Ward P, Huddy J, Hargreaves S, Tourquet R, Hurley J, Fothergill J. Primary care in London: an evaluation of general practitioners working in an inner city accident and emergency department. J Accid Emerg Med. 1996;13:11-5.

26. Myers P. Management of minor medical problems and trauma: general practice or hospital? J R Soc Med. 1982;75:879-83.

27. Norredam M, Mygind A, Nielsen AS, Bagger J, Krasnik A. Motivation and relevance of emergency room visits among immigrants and patients of Danish origin. Eur J Public Health. 2007;17:497-502.

28. Mestitz P. A series of 1,817 patients seen in a casualty department. Br Med $J$ 1957;2:1108-9.

29. Grant R, Ramgoolam A, Betz R, Ruttner L, Green JJ. Challenges to accessing pediatric health care in the Mississippi delta: a survey of emergency department patients seeking nonemergency care. J Prim Care Community Health. 2010; doi: 10.1177/2150131910380727.

30. Howard MS, Davis BA, Anderson C, Cherry D, Koller P, Shelton D. Patients' perspective on choosing the emergency department for nonurgent medical care: a qualitative study exploring one reason for overcrowding. J Emerg Nurs. 2005;31:429-35.

31. Northington WE, Brice JH, Zou B. Use of an emergency department by nonurgent patients. Am J Emerg Med. 2005;23:131-7.

32. Ragin DF, Hwang U, Cydulka RK, Holson D, Haley Jr LL, Richards CF, et al. Emergency medicine patients' access to healthcare (EMPATH) study investigators. Reasons for using the emergency department: results of the EMPATH study. Acad Emerg Med. 2005;12:1158-66.

33. Hunt RC, DeHart KL, Allison Jr EJ, Whitley TW. Patient and physician perception of need for emergency medical care: a prospective and retrospective analysis. Am J Emerg Med. 1996;14:635-9.

34. Koziol-McLain J, Price DW, Weiss B, Quinn AA, Honigman B. Seeking care for nonurgent medical conditions in the emergency department: through the eyes of the patient. J Emerg Nurs. 2000;26:554-63. 
35. Lee A, Lau FL, Hazlett CB, Kam CW, Wong P, Wong TW, et al. Factors associated with non-urgent utilization of accident and emergency services: a case-control study in Hong Kong. Soc Sci Med. 2000;51:1075-85.

36. Shah NM, Shah MA, Behbehani J. Predictors of non-urgent utilization of hospital emergency services in Kuwait. Soc Sci Med. 1996;42:1313-23.

37. Siminski P, Bezzina AJ, Lago LP, Eagar K. Primary care presentations at emergency departments: rates and reasons by age and sex. Aust Health Rev. 2008;32:700-9.

38. Masso M, Bezzina AJ, Siminski P, Middleton R, Eagar K. Why patients attend emergency departments for conditions potentially appropriate for primary care: reasons given by patients and clinicians differ. Emerg Med Australas. 2007;19:333-40.

39. Rassin M, Nasie A, Bechor $Y$, Weiss G, Silner D. The characteristics of selfreferrals to ER for non-urgent conditions and comparison of urgency evaluation between patients and nurses. Accid Emerg Nurs. 2006;14:20-6.

40. Harkin T, Sanders B. Hospital Emergency Departments: Health Center Strategies That May Help Reduce Their Use. United States Government Accountability Office. GAO-11-414R Health Center Strategies. 2011. http://www.gao.gov/assets/100/97416.pdf. Accessed 8 July 2016.

41. Rector TS, Venus PJ, Laine AJ. Impact of mailing information about nonurgent care on emergency department visits by Medicaid beneficiaries enrolled in managed care. Am J Manag Care. 1999;5:1505-12.

42. McWilliams DB, Jacobson RM, Van Houten HK BA, Naessens JM, Ytterberg $\mathrm{KL}$. A program of anticipatory guidance for the prevention of emergency department visits for ear pain. Arch Pediatr Adolesc Med. 2008;162:151-6. doi:10.1001/archpediatrics.2007.30.

43. Rettig BA, Shrauger DG, Recker RR, Gallagher TF, Wiltse H. A randomized study of the effects of a home diabetes education program. Diabetes Care. 1986:9:173-8.

44. Schonlau M, Mangione-Smith R, Chan KS, Keesey J, Rosen M, Louis TA, Wu SY, Keeler E. Evaluation of a quality improvement collaborative in asthma care: does it improve processes and outcomes of care? Ann Fam Med. 2005;3:200-8.

45. Caplan GA, Williams AJ, Daly B, Abraham K. A randomized, controlled trial of comprehensive geriatric assessment and multidisciplinary intervention after discharge of elderly from the emergency department-the DEED II study. J Am Geriatr Soc. 2004;52:1417-23.

46. Scott JC, Conner DA, Venohr I, Gade G, McKenzie M, Kramer AM, Bryant L, Beck A. Effectiveness of a group outpatient visit model for chronically ill older health maintenance organization members: a 2-year randomized trial of the cooperative health care clinic. J Am Geriatr Soc. 2004:52:1463-70.

47. Bird SR, Kurowski W, Dickman GK, Kronborg I. Integrated care facilitation for older patients with complex health care needs reduces hospital demand. Aust Health Rev. 2007;31:451-61. Author Affiliations: Division of Community Pediatric and Adolescent Medicine (Drs McWilliams, Jacobson, and Ytterberg) and Department of Health Sciences Research (Ms Van Houten and Dr Naessens), Mayo Clinic, Rochester, Minnesota.

48. Munro J, Sampson F, Nicholl J. The impact of NHS direct on the demand for out-of-hours primary and emergency care. J Gen Pract. 2005;55:790-2.

49. Turner J, O'Cathain A, Knowles E, Nicholl J. Impact of the urgent care telephone service NHS 111 pilot sites: a controlled before and after study. BMJ Open. 2013:3:e003451. doi:10.1136/bmjopen-2013-003451.

50. Thijssen WA, Wijnen-van Houts M, Koetsenruijter J, Giesen P, Wensing M. The impact on emergency department utilization and patient flows after integrating with a general practitioner cooperative: an observational study. Emerg Med Int. 2013;2013:364659. doi:10.1155/2013/364659.

51. Schäfer W, Kroneman M, Boerma W, van den Berg M, Westert G, Devillé W, et al. The Netherlands: health system review. Health Syst Transit. 2010;12:1-229.

52. Boyle S. United kingdom (England): health system review. Health Syst Transit. 2011:13:1-486

53. Rijksoverheid. Hoeveel eigen risico moet ik betalen voor mijn zorgverzekering? [How high is my deductible excess?] https://www.rijksoverheid.nl/onderwerpen/ zorgverzekering/vraag-en-antwoord/eigen-risico-zorgverzekering?utm_ campaign=sea-t-gezondheid_en_zorg-a-zorgverzekering_eigen_risico\&utm_ term=eigen\%20risico\%202016\&gclid=CP3mu672z80CFe4y0wodGq8PbA. Accessed 12 July 2016.

54. Hospital Episode Statistics Analysis, Health and Social Care Information Centre. Hospital Episode Statistics, Accident and Emergency Attendances in England 2012-13. 2014. http://content.digital.nhs.uk/catalogue/PUB13464/acci-emeratte-eng-2012-2013-rep.pdf. Accessed 12 July 2016.
55. Baker C. Accident and Emergency Statistics. Briefing paper. Number 6964, 2015. http://researchbriefings.files.parliament.uk/documents/SN06964/ SN06964.pdf. Accessed 13 July 2016.

56. National Health Atlas, version 4.16. 2014. https://www.volksgezondheidenzorg. info/onderwerp/acute-zorg/regionaal-internationaal/seh\#node-reistijd-minutennaar-dichtstbijzijnde-ziekenhuis-met-seh-met-de-auto. Accessed 8 July 2016.

57. Rice T, Rosenau P, Unruh LY, Barnes AJ, Saltman RB, van Ginneken E. United States of America: health system review. Health Syst Transit. 2013;15:1-431.

58. Gonzalez Morganti K, Bauhoff S, Blanchard JC, Abir M, lyer N, Smith AC, et al. The Evolving Role of Emergency Departments in the United States. RAND cooperation. 2013. http://www.rand.org/content/dam/rand/pubs/ research_reports/RR200/RR280/RAND_RR280.pdf. Accessed 8 July 2016. Accessed 6 July 2016

59. Marken S. U.S. Uninsured Rate at $11.4 \%$ in Second Quarter. July 2015. http:// www.gallup.com/poll/184064/uninsured-rate-second-quarter.aspx. Accessed 6 July 2016.

60. Health Resources \& Services Administration. HRSA fact sheet. 2016. http:// www.bphc.hrsa.gov/about/healthcenterfactsheet.pdf. Accessed 8 July 2016.

61. Tang N, Stein J, Hsia RY, Maselli JH, Gonzales R. Trends and characteristics of US emergency department visits, 1997-2007. JAMA. 2010;304:664-70. doi: 10.1001/jama.2010.1112

62. Ambulatory and Hospital Care. National Hospital Ambulatory Medical Care Survey: 2011 Emergency Department Summary Tables. https://www.cdc. gov/nchs/data/ahcd/nhamcs_emergency/2011_ed_web_tables.pdf. Accessed 16 July 2016.

63. Marketing General Incorporated. 2015 ACEP Poll Affordable Care Act Research Results. 2015. http://www.cmanet.org/files/assets/news/2015/05/ 2015acepacapollreportfinal-1.pdf. Accessed 8 July 2016.

64. National Center for Health Statistics. Health, United States, 2012: With Special Feature on Emergency Care. Hyattsville, MD. 2013. http://www.cdc. gov/nchs/data/hus/hus12.pdf. Accessed 6 July 2016.

65. Healy J, Sharman E, Lokuge B. Australia: health system review. Health Syst Transit. 2006:8:1-158.

66. AlHW. Emergency department care 2014-15: Australian hospital statistics. Health services series no. 65. Cat. no. HSE 168. Canberra: AlHW. 2015. http:// www.aihw.gov.au/WorkArea/DownloadAsset.aspx?id=60129553618. Accessed 17 July 2016.

67. Mian O, Pong R. Does better access to FPs decrease the likelihood of emergency department use? results from the primary care access survey. Can Fam Physician. 2012;58:658-66.

\section{Submit your next manuscript to BioMed Central and we will help you at every step:}

- We accept pre-submission inquiries

- Our selector tool helps you to find the most relevant journal

- We provide round the clock customer support

- Convenient online submission

- Thorough peer review

- Inclusion in PubMed and all major indexing services

- Maximum visibility for your research

Submit your manuscript at www.biomedcentral.com/submit 